Gut, 1982, 23, 608-614

\title{
Male gonadal function in coeliac disease: 1 . Sexual dysfunction, infertility, and semen quality
}

\author{
M J G FARTHING, C R W EDWARDS, L H REES, and A M DAWSON \\ From the Departments of Gastroenterology and Endocrinology, St Bartholomew's Hospital, London
}

SUMmaRY The prevalence of hypogonadism, sexual dysfunction and abnormalities of semen quality was determined in 28 consecutive males with coeliac disease. These observations were related to jejunal morphology and nutritional status, and were compared with findings in 19 men with Crohn's disease of similar age and nutritional status. Two of the 28 coeliacs (7\%) had clinical evidence of hypogonadism but impotence and decreased sexual activity occurred more commonly, the latter apparently improving after gluten withdrawal. Of the married coeliacs, $19 \%$ had infertile marriages, a value greater than expected in the general population. Hypogonadism and sexual dysfunction were not detected in our patients with Crohn's disease. Seminal analysis in coeliacs revealed marked abnormalities of sperm morphology and motility, but only the former appeared to improve after gluten withdrawal. Similar abnormalities, however, were also detected in patients with Crohn's disease, although, unlike the coeliacs, $46 \%$ also had reduced concentrations of spermatozoa. Semen quality in coeliac disease could not be clearly related to general or specific (serum vitamin $B_{12}$ and red cell folate) nutritional deficiencies or to fertility, although sperm motility was markedly reduced in two of the three coeliacs with infertile marriages. The presence of antisperm antibodies did not appear to be an important aetiological factor in male infertility in coeliac disease. The pathogenesis of infertility and sexual dysfunction in coeliac disease remains unclear, suggesting that factors such as endocrine dysfunction or other specific nutritional deficiency may be involved.

Unexplained infertility and hypogonadism have been observed in some patients with coeliac disease $^{1-3}$ and gluten withdrawal has been associated with an increase in sperm count and sperm motility ${ }^{3}$ and successful pregnancy in previously infertile women. ${ }^{2}$ The prevalence of gonadal dysfunction in coeliac disease has not been clearly established. The pathophysiological mechanisms involved are unknown, although nutritional deficiencies are likely to be important factors. ${ }^{4-6}$ However, reversible androgen resistance ${ }^{7}$ and hyperprolactinaemia ${ }^{8}$ have been described in men with coeliac disease and may also be involved in the pathogenesis of infertility ${ }^{9}$ and sexual dysfunction 1011 in these patients.

The aim of the present study was to determine the prevalence of infertility, sexual dysfunction, and

\footnotetext{
* Address for correspondence: Dr M J G Farthing. Tufts-New England Medical Center, Division of Geographic Medicine, 136 Harrison Avenue, Box 22, Boston, Massachusetts 02111, USA.

Received for publication 8 December 1981
}

disturbances of semen quality in men with coeliac disease and to relate these findings to jejunal morphology. We also examined the relationship between these findings and nutritional status, and have attempted to determine the specificity of these observations in coeliacs by performing similar studies in men with Crohn's disease.

\section{Methods}

\section{PATIENTS}

Twenty-eight consecutive men with coeliac disease (median age 38 years, range 15-71 years) and 19 men with Crohn's disease (median age 29 years, range 22-58 years) were studied. All patients gave their informed consent before taking part in the study.

\section{Diagnosis and disease activity}

The diagnosis of coeliac disease was based on the morphological appearances of an initial jejunal 
biopsy with subsequent improvement in jejunal morphology after gluten withdrawal. Patients were classified according to jejunal histology into three groups - namely, subtotal villous atrophy (11 patients) partial villous atrophy (nine patients), or a normal mucosa (eight patients). Patients with subtotal villous atrophy were not taking a glutenfree diet except for two, one of whom responded very slowly to gluten withdrawal but subsequently achieved classification as partial villous atrophy and another who admitted to intermittently taking gluten in his diet. All patients with subtotal villous atrophy eventually after gluten withdrawal had demonstrable improvement in jejunal morphology. The rest of the patients with partial villous atrophy and the normal patients were all taking gluten-free diet.

The patients with Crohn's disease all had both colonic and small intestinal disease with characteristic radiological and histological features. Disease activity was assessed using an activity score $^{12}$ which took into account clinical data and the results of laboratory investigations. Activity ranged between 2-14 units and, for presentation of results, patients were divided arbitrarily into those with low disease activity, 0-5 units (eight patients) and those with high disease activity, greater than 5 units (11 patients). At the time of study, three patients were receiving prednisolone $3-5 \mathrm{mg}$ daily, three were receiving sulphasalazine $1-3 \mathrm{~g}$ daily, and five azathioprine $50-150 \mathrm{mg}$ daily. A total of eight patients were receiving one or more of these drugs, but the remaining 11 were receiving none.

\section{PROCEDURES}

Clinical features and nutritional status (Table 1)

The distribution of body hair, the presence or absence of gynaecomastia ${ }^{13}$ and galactorrhoea, and testicular volume using an orchidometer ${ }^{14}$ were determined during physical examination. The consistency of the testes were assessed as being firm or soft, and the presence of other abnormlities such as varicocoeles were noted.

Height and weight were measured, and body weight as percentage of the ideal body weight was determined. ${ }^{15}$ Triceps skin-fold thickness (mean of five estimates) using Harpenden skin-fold calipers and circumference of the non-dominant arm at the mid-point between the olecranon process and the acromion were measured, from which the arm muscle circumference was derived. Each of the parameters were then expressed as percentage of a standard. ${ }^{15}$

Blood was taken for measurement of serum albumin, serum vitamin $B_{12}$, and red blood cell folate.

\section{Sexual function}

Sexual function was assessed by one of us during a structured interview. Patients were asked to rate the strength of their libido as either strong (4), moderately strong (3), moderate (2), mild (1), or none (0), and to estimate the frequency of sexual activity (coitus or masturbation) during the preceding month, from which an average weekly rate of sexual events was determined. A more objective estimate of the level of sexual activity was

Table 1 Nutritional parameters (median and range) in patients with coeliac disease and Crohn's disease

\begin{tabular}{|c|c|c|c|c|c|c|c|}
\hline \multirow[b]{2}{*}{ Disease } & \multirow[b]{2}{*}{$\begin{array}{l}\text { Disease } \\
\text { activity }\end{array}$} & \multirow[b]{2}{*}{$\begin{array}{l}\text { Body weight } \\
\% \text { ideal BW }\end{array}$} & \multicolumn{2}{|l|}{$\%$ Standard ${ }^{*}$} & \multirow[b]{2}{*}{$\begin{array}{l}\text { Serum } \\
\text { albumin } \\
(g / l)\end{array}$} & \multirow[b]{2}{*}{$\begin{array}{l}\text { Red cell } \\
\text { folate } \\
\text { (ng/l) }\end{array}$} & \multirow[b]{2}{*}{$\begin{array}{l}\text { Serum } \\
\text { vitamin } B_{12} \\
(\mu g / l)\end{array}$} \\
\hline & & & $\begin{array}{l}\text { Mean triceps } \\
\text { skinfold } \\
\text { thickness }\end{array}$ & $\begin{array}{l}\text { Non-dominant } \\
\text { arm muscle } \\
\text { circum- } \\
\text { ference }\end{array}$ & & & \\
\hline \multirow[t]{3}{*}{ Coeliac disease } & $\mathbf{N}$ & $\begin{array}{c}93 \\
(77-108)\end{array}$ & $\begin{array}{l}122 \\
(73-136)\end{array}$ & $\begin{array}{c}95 \\
(66-105)\end{array}$ & $\begin{array}{c}42 \\
(40-47)\end{array}$ & $\begin{array}{l}357 \\
(217-591)\end{array}$ & $\begin{array}{l}421 \\
(210-625)\end{array}$ \\
\hline & PVA & $\begin{array}{l}103 \\
(70-127)\end{array}$ & $\begin{array}{c}86 \\
(61-93)\end{array}$ & $\begin{array}{c}92 \\
(70-111)\end{array}$ & $\begin{array}{c}42 \\
(38-46)\end{array}$ & $\begin{array}{l}254 \\
(168-572)\end{array}$ & $\begin{array}{l}343 \\
(215-615)\end{array}$ \\
\hline & SVA & $\begin{array}{c}97 \\
(72-113)\end{array}$ & $\begin{array}{c}76 \\
(50-100)\end{array}$ & $\begin{array}{c}87 \\
(70-108)\end{array}$ & $\begin{array}{c}40 \\
(27-43)\end{array}$ & $\begin{array}{l}109 \\
(56-250)\end{array}$ & $\begin{array}{l}150 \\
(90-415)\end{array}$ \\
\hline \multirow[t]{2}{*}{ Crohn's disease } & CDAS 0-5 & $\begin{array}{c}97 \\
(77-108)\end{array}$ & $\begin{array}{l}60 \\
(43-114)\end{array}$ & $\begin{array}{c}92 \\
(82-102)\end{array}$ & $\begin{array}{c}38 \\
(34-44)\end{array}$ & $\begin{array}{l}283 \\
(176-640)\end{array}$ & $\begin{array}{l}310 \\
(165-470)\end{array}$ \\
\hline & CDAS $>5$ & $\begin{array}{c}89 \\
(77-99)\end{array}$ & $\begin{array}{c}55 \\
(32-96)\end{array}$ & $\begin{array}{c}86 \\
(64-99)\end{array}$ & $\begin{array}{c}40 \\
(29-43)\end{array}$ & $\begin{array}{l}420 \\
(112-640)\end{array}$ & $\begin{array}{l}450 \\
(205-660)\end{array}$ \\
\hline Normal values & & 100 & 100 & 100 & $35-50$ & $160-640$ & $160-900$ \\
\hline
\end{tabular}

Serum albumin: SVA vs $\mathrm{N}, \mathrm{p}<0 \cdot 01$; Red cell folate/serum vitamin $\mathrm{B}_{12}$ : SVA $v s \mathrm{~N}, \mathrm{p}<0.001$; SVA $v s \mathrm{CD}, \mathrm{p}<0 \cdot 001$. $\mathrm{N}$, normal jejunal morphology; PVA, partial villous atrophy; SVA, subtotal villous atrophy; CDAS, Crohn's disease activity score; BW, body weight; CD Crohn's disease.

* Jelliffe. ${ }^{15}$ 
made by enquiry into the frequency of early morning erections. Patients were asked to describe any sexual difficulties, particularly impotence.

\section{Fertility}

A retrospective assessment of fertility was made by determining which patients had fathered children, whether delays in conception had occurred, and the nature of their contraceptive practices.

\section{Seminal analysis}

Patients with coeliac disease and Crohn's disease were invited to produce a sample of semen by masturbation after at least four days' abstinence. Age did not differ significantly in the three morphological subgroups of coeliacs who produced semen for analysis (Table 2). Seminal analysis included measurement of sperm density, motility, the presence and proportion of abnormal forms of spermatozoa, and the volume of ejaculate. Seminal plasma was examined for the presence of antisperm antibodies by two agglutination tests, the gelatin agglutination test (GAT), ${ }^{16}$ and the Tray agglutination test. ${ }^{17}$ In some patients, sperms were tested directly using the mixed antiglobulin reaction. ${ }^{18}$

\section{Statistical analyses}

Comparisons between groups were examined by the Mann-Whitney U test.

\section{Results}

CLINICAL EVIDENCE OF HYPOGONADISM

Two of the 28 coeliacs (7\%), both of whom were untreated with subtotal villous atrophy, had marked reduction of facial, pubic, and axillary hair. One of these patients had soft testes and reduced mean testicular volume $(12 \mathrm{ml})$. This latter patient had been diagnosed in infancy but failed to adhere to a gluten-free diet, whereas the other did not become symptomatic until the age of 69 years.

With the exception of one pubertal male who had a testicular volume of $10 \mathrm{ml}$, the remaining coeliacs had normal body hair and testicular volume (greater than $15 \mathrm{ml})^{14}$ and firm testicular consistency. None of the coeliacs had gynaecomastia, galactorrhoea, or a varicocoele. Clinical evidence of hypogonadism or feminisation was not apparent in any of the 19 control patients with Crohn's disease.

\section{NUTRITIONAL STATUS}

Body weight as a percentage of the ideal body weight for height, mean triceps skin fold thickness (\% standard), and non-dominant arm muscle circumference ( $\%$ standard) were not significantly different in coeliacs with subtotal villous atrophy and patients with high activity Crohn's disease, the two most severely ill disease sub-groups (Table 1). These findings suggest that these coeliacs and patients with Crohn's disease were well matched

Table 2 Seminal analysis (median and range) in patients with coeliac disease and Crohn's disease

\begin{tabular}{|c|c|c|c|c|c|c|c|c|c|}
\hline \multirow[b]{2}{*}{ Disease } & \multirow{2}{*}{$\begin{array}{l}\text { Disease } \\
\text { activity }\end{array}$} & \multirow{2}{*}{$\begin{array}{l}\text { Number } \\
\text { examined }\end{array}$} & \multirow{2}{*}{$\begin{array}{l}\text { Sperm } \\
\text { density } \\
\times 10^{6} / \mathrm{ml}\end{array}$} & \multirow{2}{*}{$\begin{array}{l}\text { Abnormal } \\
\text { forms } \\
(\%)\end{array}$} & \multirow{2}{*}{$\begin{array}{l}\text { Motility } \\
\text { (\%) }\end{array}$} & \multirow{2}{*}{$\begin{array}{l}\text { Volume of } \\
\text { ejaculate } \\
\text { (ml) }\end{array}$} & \multicolumn{3}{|c|}{$\begin{array}{l}\text { Antisperm antibodies } \\
\text { (no. positive) }\end{array}$} \\
\hline & & & & & & & $M A R$ & $G A T$ & $T A T$ \\
\hline \multirow[t]{3}{*}{ Coeliac disease } & $\mathbf{N}$ & 6 & $\begin{array}{c}82 \\
(40-190)\end{array}$ & $\begin{array}{c}23 \\
(18-48)\end{array}$ & $\begin{array}{c}50 \\
(20-72)\end{array}$ & $\begin{array}{c}2 \cdot 8 \\
(1 \cdot 5-5 \cdot 0)\end{array}$ & 0 & 0 & 1 \\
\hline & PVA & 5 & $\begin{array}{c}68 \\
(24-755)\end{array}$ & $\begin{array}{c}30 \\
(24-36)\end{array}$ & $\begin{array}{c}50 \\
(40-60)\end{array}$ & $\begin{array}{c}2 \cdot 0 \\
(1 \cdot 0-2 \cdot 3)\end{array}$ & 0 & 0 & 1 \\
\hline & SVA & 5 & $\begin{array}{c}82 \\
(75-220)\end{array}$ & $\begin{array}{c}56 \\
(32-89)\end{array}$ & $\begin{array}{c}40 \\
(10-60)\end{array}$ & $\begin{array}{c}1 \cdot 6 \\
(1 \cdot 0-2 \cdot 4)\end{array}$ & 0 & 0 & 0 \\
\hline Crohn's disease & CDAS 2-14 & 13 & $\begin{array}{c}57 \\
(0.4-302)\end{array}$ & $\begin{array}{c}32 \\
(18-84)\end{array}$ & $\begin{array}{c}25 \\
(15-70)\end{array}$ & $\begin{array}{c}1 \cdot 7 \\
(0 \cdot 7-3 \cdot 2)\end{array}$ & 0 & 0 & 0 \\
\hline \multirow[t]{2}{*}{ Normal values* } & - & - & $>40$ & $<30$ & $>60$ & $>1 \cdot 0$ & - & - & - \\
\hline & \multicolumn{2}{|c|}{$\begin{array}{l}\text { Age (yr) } \\
\text { (median and range) }\end{array}$} & & & & & & & \\
\hline $\begin{array}{l}\text { Coeliac disease } \\
\text { N } \\
\text { PVA } \\
\text { SVA } \\
\text { Crohn's disease }\end{array}$ & \multicolumn{2}{|c|}{$\begin{array}{l}35(21-51) \\
45(37-62) \\
45(33-60) \\
30(21-53)\end{array}$} & & & & & & & \\
\hline
\end{tabular}

MAR: mixed antiglobulin reaction. GAT: gelatin agglutination test. TAT: tray agglutination test.

* Zaneveld and Polakoski. ${ }^{40}$ 
with regard to general nutritional state. However, all of the patients with high activity Crohn's disease and $75 \%$ of coeliacs with subtotal villous atrophy were below their ideal body weight. After gluten withdrawal and complete recovery of the jejunal mucosa, $64 \%$ of the coeliacs remained below their ideal body weight.

Serum albumin concentration was not significantly different in coeliacs with subtotal villous atrophy and patients with high activity Crohn's disease, thus confirming the similarity in nutritional status of these patients. Coeliacs with subtotal villous atrophy, however, had significantly lower serum albumin than those with a normal jejunal mucosa. Red blood cell folate and serum vitamin $B_{12}$ were significantly lower in coeliacs with subtotal villous atrophy than patients with high activity Crohn's disease, although in coeliacs both returned towards normal after gluten withdrawal.

\section{SEXUAL FUNCTION}

\section{Libido}

Self-rated libido (0-4) was not significantly different in patients with Crohn's disease (median 2, range $1-4)$ and coeliac disease (median 3, range $0-4$ ). Similarly, no differences in libido rating were apparent between patients with untreated and treated coeliac disease. The frequency of sexual events each week, however, was significantly lower in coeliacs with subtotal villous atrophy (median 1.0, range 1-2) than coeliacs with a normal jejunal biopsy (median 2.5 , range $0.5-10, p<0.05$ ) and patients with Crohn's disease (median 2.3, range $0 \cdot 1-7, p<0 \cdot 01$ ). In addition, early morning erections occurred less frequently in coeliacs with subtotal villous atrophy (median 0, range 0-4) than in patients with Crohn's disease (median 1.8 , range $0-7, \mathrm{p}<0.025)$.

\section{Impotence}

Intermittent or persistent erectile impotence was found in five of 26 adult males with coeliac disease but none of the patients with Crohn's disease. Complete impotence occurred in the two male coeliacs with subtotal villous atrophy who had overt clinical evidence of hypogonadism. A third coeliac with subtotal villous atrophy was impotent intermittently, as were the remaining two patients, one of whom had partial villous atrophy and the other a normal jejunal biopsy. The patient with subtotal villous atrophy and intermittent sexual dysfunction had previously had an anterior resection for carcinoma of the colon which may have been a contributing factor. In the remaining four patients there were no obvious organic or psychological explanations, nor were they receiving any medication that could account for the impotence.

\section{Fertility}

Thirteen of the 16 married coeliacs produced 27 normal children, 23 of which were conceived before the diagnosis of coeliac disease had been made. In none of these patients was there any significant delay before conception. Only three of these 13 men confidently recollected gastrointestinal symptoms throughout childhood and adolescence. Of the three married men without children (19\%) two had regular coitus but had never used any form of contraception and the wife of the third had failed to become pregnant after regular coitus for 18 months without contraception. None of the single adult male coeliacs was of proven fertility. Seven of the 10 married men with Crohn's disease produced 11 normal children. Of the remaining three, two were using adequate contraception but the wife of the third had failed to become pregnant despite discontinuation of contraceptive measures three years previously.

\section{SEMINAL ANALYSIS}

Of the 26 adult coeliacs, 16 were able to produce a specimen of semen, four declined, three failed because of impotence, and three were willing but unable to produce a specimen on demand. Thirteen of the 18 adult men with Crohn's disease produced a specimen of semen, the remaining five declined. The results of seminal analyses and antisperm antibodies, including normal values, are shown in Table 2.

\section{Sperm density}

Only one of the 16 patients with coeliac disease (partial villous atrophy) had a sperm density of less than $\mathbf{4 0}$ million spermatozoa per $\mathrm{ml}$, compared with six of 13 patients with Crohn's disease $\left(\chi^{2}=4 \cdot 5\right.$, $\mathrm{p}<0.05)$. These oligospermic patients with Crohn's disease had either never received sulphasalazine or had not taken it during the preceding year. Four of these six patients with Crohn's disease were receiving azathioprine. Although nutritional status was equivalent in patients with coeliac disease and Crohn's disease (Table 1), in the subgroups of patients in whom seminal analysis was performed, body weight, triceps skin fold thickness, and serum albumin were modestly but significantly lower in patients with Crohn's disease than those with coeliac disease $(p<0 \cdot 025)$. Hence undernutrition may have contributed to the increased prevalence of oligospermia in these patients with Crohn's disease. There was no obvious relationship between sperm density and jejunal morphology in patients with coeliac disease. 
Abnormal forms of spermatozoa

There was no significant difference between the percentage of abnormal forms in coeliacs and patients with Crohn's disease. However, six of 13 coeliacs $(46 \%)$ and four of nine patients with Crohn's disease $(44 \%)$ had more than $30 \%$ abnormal forms. In patients with coeliac disease, the proportion of abnormal forms in patients with a normal jejunal mucosa (median $23 \%$, range 18-48) was significantly lower than those with subtotal villous atrophy (median $40 \%$, range 10-60; $\mathrm{p}<0.02$ ). Two of the four patients with Crohn's disease with raised levels of abnormal forms were receiving sulphasalazine.

\section{Sperm motility}

A striking abnormality was that 12 of 16 coeliacs $(75 \%)$ and 11 of 13 patients with Crohn's disease (85\%) had impaired sperm motility. Sperm motility was not significantly different in patients with Crohn's disease and coeliac disease, and in coeliac disease motility failed to increase after gluten withdrawal and recovery of the jejunal mucosa.

\section{Volume of ejaculate}

There was no significant difference in the volume of ejaculate in patients with coeliac disease and those with Crohn's disease, although two of the latter had volumes of less than $1 \mathrm{ml}$, both of whom had sperm densities of less than 40 million per ml. Coeliacs with partial villous atrophy and subtotal villous atrophy had significantly lower volumes than those in whom the mucosa had returned to normal $(\mathrm{p}<0 \cdot 02)$.

\section{Antisperm antibodies}

Two patients with coeliac disease had weakly positive (titre 1 in 8 ) antisperm antibodies by the Tray agglutination method, although other tests failed to confirm their presence. None of the patients with Crohn's disease had antisperm antibodies.

\section{SEMEN QUALITY, NUTRITIONAL FACTORS, AND FERTILITY}

Semen quality in two of the three coeliacs with infertile marriages was suboptimal. Although sperm density was greater than 40 million per $\mathrm{ml}$ and the percentage of abnormal forms of spermatozoa did not exceed $32 \%$, both had reduced sperm motilities $(10 \%$ and $25 \%)$, which were the lowest values of all the coeliacs studied. Antisperm antibodies were negative by all of the tests used in this study. The third patient was impotent and unable to produce a specimen of semen. The patient with Crohn's disease with an infertile marriage had a markedly reduced sperm density $(0.4 \times 106 / \mathrm{ml})$ and sperm motility (15\%); this was sufficient to account for the failure of his wife to conceive. The only coeliac patient with reduced sperm density was unmarried and of unproven fertility. Of the two patients with weakly positive antisperm antibodies, one was unmarried but the other was fertile with two children.

Although serum vitamin $B_{12}$ and red cell folate were significantly lower in coeliacs with subtotal villous atrophy than patients with Crohn's disease, there were not obvious differences in sperm density, motility, or the proportion of abnormal forms of spermatozoa in these groups of patients. In addition, neither serum vitamin $B_{12}$ or red cell folate correlated significantly with any of the above parameters obtained by seminal analysis.

\section{Discussion}

An investigation of hypogonadism, sexual function, and fertility in a non-endocrine disease, in this case coeliac disease, must adequately control for the effects of chronic illness and malnutrition, as they may influence gonadal function independently of any other underlying disease process. ${ }^{4-6} 19 \mathrm{~A}$ vital observation in the present study was the similarity in nutritional status in patients with coeliac disease and Crohn's disease. This means that clinical and biochemical differences between these two conditions are likely to be related to the disease rather than the general effects of malnutrition.

\section{CLINICAL FEATURES OF HYPOGONADISM IN}

COELIAC DISEASE

Clinical evidence of hypogonadism was present in two of 28 males $(7 \%)$ in the present study, a prevalence which is almost identical with that reported by Cooke et al ${ }^{1}$ when three of 49 men $(6 \%)$ spontaneously complained of impotence with associated loss of facial and axillary hair. An earlier study $^{20}$ reported poor development of secondary sex characteristics in four of seven men with coeliac disease, although it is not entirely clear as to whether this was due primarily to delayed puberty or a secondary phenomenon after puberty. Perloff $e t$ at drew attention to similarities between the clinical appearance of a patient with coeliac disease and hypopituitarism, and this was again emphasised in a recent review of clinical aspects of coeliac disease. ${ }^{21}$ Other substantial clinical studies of patients with coeliac disease fail to comment on the occurrence of the clinical features of hypogonadism or sexual dysfunction. ${ }^{22} 23$

The present study and that of Cooke $\mathrm{et} \mathrm{al}^{1}$ suggest that overt hypogonadism is an infrequent finding in men with coeliac disease. Although present in only 
two patients, the findings of this study indicate that severe symptoms during puberty or onset in later life, when gonadal and sexual function are declining, may be important factors in producing clinical hypogonadism in coeliac disease. Three other patients in the present study also complained of impotence, without additional clinical features of hypogonadism, which gives an overall prevalence of $18 \%$. Whatever the mechanisms involved, this is higher than would be expected, as impotence is present in only $7.6 \%$ of men at the age of 50 years; ${ }^{24}$ four of the five impotent coeliacs in this study were 45 years old or less. In addition, impotence was not found in any of the patients with Crohn's disease who were of a similar age distribution.

Although subjective assessment of libido was unaltered in males with coeliac disease, the diminished frequency of weekly sexual events and early morning erections in untreated coeliacs, with apparent improvement after gluten withdrawal, supports the view that milder but significant degrees of sexual dysfunction occur in untreated coeliacs.

\section{FERTILITY}

This limited series of male coeliacs is not large enough to draw any firm conclusions regarding the prevalence of infertility in this condition. However, three of the 16 marriages $(19 \%)$ appeared to be infertile, which is greater than expected in the general population, ${ }^{25}$ and seminal analysis performed in two of these patients was abnormal, the most remarkable feature being reduction in sperm motility. Cooke et $a^{1}$ found that 11 of 38 married men had no children, suggesting that $29 \%$ of those marriages were infertile, again a higher figure than could be expected.

Both of the infertile coeliac men reported by Baker and Read $^{3}$ had reduced sperm density and motility, but only the motility returned to normal after gluten withdrawal, an observation which was not found in the present study, where the only parameter of seminal analysis which appeared to improve after gluten withdrawal was the proportion of abnormal spermatozoa.

The relationship between semen abnormalities and fertility in men with coeliac disease cannot be adequately determined by this retrospective analysis, as semen quality of men of proven fertility at the time of conception was unknown. As reduced sperm motility and an increase in the proportion of abnormal forms of spermatozoa was also found in patients with Crohn's disease, there is no direct evidence that these changes are disease specific and may well be the result of chronic illness. However, half of the patients with Crohn's disease with increased numbers of abnormal spermatozoa were receiving sulphasalazine, which is known to produce this effect in males with ulcerative colitis, ${ }^{26}$ although the reduction in sperm density in our patients with Crohn's disease could not be attributed to this drug.

\section{PATHOGENESIS OF GONADAL DYSFUNCTION}

Although the general effects of protein and energy deprivation may result in hypogonadism, ${ }^{6} 19$ the objective measures of nutritional status used in the present study indicated that general nutritional disturbance was not severe, and was similar in coeliacs and control subjects with Crohn's disease. This would suggest that other factors are likely to be involved. $B_{12}$ and folic acid deficiency occur in coeliac disease, and were present in some of the untreated coeliacs in this study. Deficiency of vitamin $B_{12}$ has been implicated as a cause of male infertility in men with pernicious anaemia, ${ }^{27} 28$ but in the present study there was no obvious relationship between vitamin $B_{12}$ levels, fertility, and semen quality. Folic acid deficiency has not been directly invoked as a cause of male infertility, although, since the original observation that sulphasalazine reduced sperm density and sperm motility ${ }^{26}$ several other reports have confirmed this finding ${ }^{29-31}$ and it has been suggested that this drug's sulphonamide moiety may interfere with spermatogenesis by impairing folic acid metabolism. Other specific deficiencies of vitamins or trace metals such as zinc ${ }^{32-34}$ may be contributory.

Antisperm antibodies in blood and seminal plasma have been implicated as a cause of male infertility 35 and screening for these antibodies is now a recognised part of the investigation of infertility. ${ }^{37}$ Although coeliac disease has been associated with a variety of disorders in which autoimmune mechanisms may be pathogenetically important ${ }^{38}$ only two patients in the present study had weakly positive agglutinating antibodies in seminal plasma, one of whom was unmarried but the other was of proven fertility. Production of antisperm autoantibodies would not seem to be an important mechanism of male infertility in coeliac disease.

Hence, there is no clear explanation for the hypogonadism, sexual dysfunction, and abnormalities of semen quality found in coeliac disease.

Androgen resistance and hyperprolactinaemia have been described in men with coeliac disease and in other circumstances have been implicated as causes of male infertility ${ }^{9}$ and sexual dysfunction. ${ }^{11}$ We discuss the relevance of these and other endocrine abnormalities to infertility and sexual dysfunction in a separate study. ${ }^{39}$

MJGF gratefully acknowledges the financial support of the Wellcome Trust. The authors also wish to thank Mr W F Hendry 
and the staff of the Williamson Laboratory, St Bartholomew's Hospital, for performing the seminal analyses, including the screening for antisperm antibodies, and for their advice in the execution of these studies. We are also grateful to Dr Parveen Kumar, Department of Gastroenterology, St Bartholomew's Hospital and Dr Robert Bown, Frimley Park Hospital, for allowing us to investigate their patients with coeliac disease and for helpful criticism throughout the study.

\section{References}

1 Cooke WT, Peeney ALP, Hawkins CF. Symptoms, signs and diagnostic features of idiopathic steatorrhea. Q J Med 1953; 22: 59-77.

2 Morris JS, Adjukiewicz AB, Read AE. Coeliac infertility: an indication for dietary gluten restriction? Lancet 1970; 1: 213-4.

3 Baker PG, Read AB. Reversible infertility in male coeliac patients. $\mathrm{Br}$ Med J 1975; 2: 316-7.

4 Jacobs EC. Effects of starvation on sex hormones in the male. J Clin Endocrinol 1948; 8: 227-32.

5 Hultgren HN. Clinical and laboratory observations in severe starvation. Stamford Med Bull 1951; 9: 175-91.

6 Perloff WH, Lasche EM, Nodine JH, Schneeberg NG, Vieillard CB. The starvation state and functional hypopituitarism. JAMA 1954; 155: 1307-13.

7 Green JRB, Goble HL, Edwards CRW, Dawson AM. Reversible insensitivity to androgens in men with untreated gluten enteropathy. Lancet 1977; 1: 280-2.

8 Stevens FM, McCarthy CF, Craig A. Is prolactin trophic to the intestine in coeliac disease? Gut 1978; 19: A992-3.

9 Aiman J, Griffin JE, Galzak JM, Wilson JD, MacDonald PC. Androgen insensitivity as cause of infertility in otherwise normal men. $N$ Engl $J$ Med 1979; 300: 223-7.

10 Friesen H, Tolis G, Shiu R, Hwng P. In: Pasteels JL, Robyn C, eds. Human prolactin. Amsterdam: Exerpta Medica, 1973.

11 Franks S, Jacobs HS, Martin N, Nabarro JDN. Hyperprolactinaemia and impotence. $J$ Clin Endocrinol 1978; 8: 277-87.

12 Willoughby JMT, Kumar PJ, Beckett J, Dawson AM. Controlled trial of azathioprine in Crohn's disease. Lancet 1971; 2: 944-7.

13 Hall PF. Gynaecomastia. Sydney: Australian Medical Publishing Co, 1959.

14 Prader, A. Testicular size: assessment and clinical importance. Triangle 1966; 7: 240-3.

15 Jelliffe DM. The assessment of the nutritional status of the community. Geneva: WHO, 1966.

16 Kilbrick S, Belding DL, Merrill B. Methods in the detection of antibodies against mammalian spermatozoa. Fertil Steril 1952; 3: 430-8.

17 Friberg J. A simple and sensitive micro-method for demonstration of sperm-agglutinating activity in serum from infertile men and women. Acta Obstet Gynecol Scand 1974; suppl. 36: 21-9.

18 Jager S, Kremer J, Van Slochteren-Draaisma T. A simple method of screening for antisperm antibodies in the human male. Detection of spermatozoal surface IgG with the direct mixed antiglobulin reaction carried out on untreated fresh human semen. Int J Fertil 1978;
23: 12-21.

19 De Kretser DM. The effects of systemic disease on the function of the testis. Clin Endocrinol Metab 1979; 8: 487-98.

20 Bennett TI, Hunter D, Vaughan JM. Idiopathic steatorrhoea (GEE's Disease). A nutritional disturbance associated with tetany, osteomalacia and anaemia. $Q J$ Med 1932; 1: 603-78.

21 Barry RE, Baker P, Read AE. Coeliac disease. The clinical presentation. Clin Gastroenterol 1974; 3: 55-69.

22 Bossak ET, Wang CI, Adlersberg D. Clinical aspects of the malabsorption syndrome: observations on 94 pts. $J$ Mt Sinai Hosp 1957; 24: 286-303.

23 Green PA, Wollaeger EE. The clinical behaviour of sprue in the United States. Gastroenterology 1960; 38: $399-418$.

24 Kinsey AC, Pomeroy WB, Martin CE. Sexual behaviour in the human male. Philadelphia: Saunders, 1948: 236.

25 Southam AL. What to do with the "normal" infertile couple. Fertil Steril 1960; 11: 543-9.

26 Levi AJ, Fisher AM, Hughes L, Hendry WF. Male infertility due to sulphasalazine. Lancet 1979; 2 : 276-8.

27 Watson AA. Seminal vitamin $\mathrm{B}_{12}$ and sterility. Lancet 1962; 2: 664 .

28 Furnass SB. Seminal vitamin $B_{12}$ and sterility. Lancet 1963; 1: 59-60:

29 Toovey S, Levi AJ, Hendry WF. Sulphaslazine and male infertility. Gut 1981; 22: 445-51.

30 Freeman JG, Reece VAC, Venables CW. Sulphasalazine and male infertility. Gut 1980; 21: A911-2.

31 Birnie GG, McLeod T, Watkinson G. Oligospermia associated with sulphasalazine therapy. Gut 1981; 22: 452-5.

32 Lei KY, Abbasi A, Prasad AS. Function of pituitarygonadal axis in zinc-deficient rats. Am J Physiol 1976; 230: $1730-2$.

33 Golden BE, Golden MHN. Plasma zinc and the clinical features of malnutrition. Am J Clin Nutr 1979; 32: $2490-4$.

34 McClain C, Soutor C, Zieve L. Zinc deficiency: A complication of Crohn's disease. Gastroenterology 1980; 78: 272-9.

35 Rumke PH. The presence of sperm antibodies in the serum of two patients with oligozoospermia. Vox Sang 1954; 4: 135-40.

36 Wilson L. Sperm agglutination due to autoantibodies: a new cause of sterility. Fertil Steril 1956; 7: 262-7.

37 Morgan H, Stedronska J, Hendry WF, Chamberlain GVP. Sperm/cervical-mucus crossed hostility testing and antisperm antibodies in the husband. Lancet 1977; 1: $1228-30$.

38 Scott BB, Losowsky MS. Coeliac disease: a cause of various associated diseases. Lancet 1975; 2: 956-7.

39 Farthing MJG, Edwards CRW, Rees LH, Dawson AM. Male gonadal function in coeliac disease: II. Sex hormones. Gut 1982. (In press.)

40 Zaneveld LJD, Polakoski KL. Collection and physical examination of the ejaculate. In: Hatez ESE, ed. Techniques of human andrology. Amsterdam: Elsevier/ North Holland: Biomedical Press, 1977. 